\title{
Malraux's Tête d'obsidienne: Revisiting the Avant-Garde
}

\author{
Rosemary Eberiel \\ Agnes Scott College (Decatur, Georgia)
}

T a Tête d'obsidienne of $1974,{ }^{1}$ Malraux's homage and memorial to Picasso, is a catalogue uof memories and dreams: of childhood and eternity, birth and resurrection, and of the familiarity and strangeness of the fruits of artistic struggle and creation. Malraux frames this tale, written in his seventy-second year, with repeated references to coincidences between his life and Picasso's. «Je mets à jour des notes de la guerre d'Espagne» (7), La Tête d'obsidienne begins, when the telephone rings. Jacqueline Picasso, the painter's widow, would enlist Malraux's assistance in leaving Picasso's collection of paintings to the state (8). Spain is the point of reference to which Malraux most often returns in evoking his visit with Jacqueline. He remembers the conversation he had with the painter when he was on leave from the Spanish Civil War and Picasso was painting Guernica (17). He remembers speaking with Picasso in 1937, before Guernica was taken to the Spanish Republican Pavilion at the Paris World's Fair (41-53). To these memories of the painter of Guernica and the author of L'Espoir (1937), Malraux adds those of a visit he had with Picasso in 1945. The writer, still in uniform, was received by a more eccentrically clad Picasso in the Grands Augustins studio (130). It was there, he recalls, that Picasso asked him for the first time about the musée imaginaire (97). Finally, Malraux remembers his encounter with Picasso's paintings at the 1966 Grand Palais retrospective exhibition which he says he organized in his role as Minister for Cultural Affairs in de Gaulle's government (9). ${ }^{2}$ These recollections, which coincide with heroic moments in Malraux's public life, serve to situate his meditation on a high and solemn plane suitable to a book that is a memorial to one of the greatest painters of the twentieth century and a meditation on the musée imaginaire as embodied in the 1973 exhibition mounted in Malraux's honor at the Fondation Maeght in Saint-Paul-deVence. ${ }^{3}$ As for the private Picasso, Malraux says he never knew him (12). La Tête $d^{\prime}$ obsidienne then is not to be about run miserable petit tas de secrets,,$^{4}$ but about the grandeur and mystery of human creation. 
Nothing is ever so simple in Malraux's work, of course, and it is not for nothing that he evokes Lear's fool and Chats bottés and Don Quixote $(243,188,244)$. In 1970, three years before the publication of $L a$ Tête d'obsidienne, Malraux had offered to form and lead a foreign legion battalion to fight for Bengla Desh. ${ }^{5}$ One thinks of the old conqueror at the end of Royaume farfelu (1928) who dreams of setting sail and observes, «J'ai soixante ans $a$ peine. ${ }^{6}$ In wandering about the disembodied shades of the musée imaginaire and the Martian thicket of paintings and fetishes piled up and dreaming in Picasso's ateliers $(72,45)$, Malraux leaves a trail of clues that lead the uncertain way to another series of artistic encounters as important for understanding his work as those he marks with his more official imprimatur. Like the papiers collés of Synthetic Cubism, with their witty metonymic play of signifiers borrowed from various registers of reality and representation, Malraux works are full of signs and names. ${ }^{7}$ Among the former are the familiar cats and butterflies who find their way into all of his works, including $\mathrm{La}$ Tête d'obsidienne $(28,34,158,180,166,199) .{ }^{8}$ Among the latter are names Malraux uttered with less frequency but pronounced with no less talismanic resonance in La Tête d'obsidienne. These include Fernand Léger, who illustrated Malraux's Lunes en papier of 1921, and Daniel-Henri Kahnweiler. In observing a painting by Le Nain in Picasso's studio, Malraux remarks that it was once in his father's dining room in Bois-Dormant, that it had belonged to his aunt, and that he himself had sold it to Kahnweiler who passed it along to Picasso. Malraux tells this story as though in passing, noting casually that it is a small world (21). Later in the book however, Andre Breton shows up in the guise of a sféticheur découragé" to remind Malraux that there are no coincidences, only magic (157). Of all the names Malraux invokes, the most telling are those of poets, including Jacob, Salmon, and especially Apollinaire, with whom Malraux served his artistic apprenticeship and who are at least as significant to his artistic development as the painter who was their friend. «Apollinaire, il ne connaissait rien de la peinture» Malraux's Picasso observes, «pourtant, il aimait la vraie. Les poètes, souvent, ils devinent. Au temps du Bateau Lavoir, les poètes devinaient....» (113) Jacob, Salmon, and Apollinaire knew Picasso in his earliest days in Paris in the first decades of the century. Apollinaire died in 1918, of course, but Malraux knew his milieu and works through Jacob and others. In 1972 he confided to Jean Lacouture, «[a] vingt ans, nous subissions ... des influences esthétiques - la plus importante était celle d'Apollinaire, dont Max Jacob assurait en quelque sorte le relais .....

In an interview in Le Monde following the publication of La Tête d'obsidienne, Malraux was asked whether the second, forthcoming volume of Le Miroir des limbes would include his recollections of the Bateau Lavoir, the ramshackle building that was home and meeting place for Picasso and other artists and poets of his group. Malraux deflects the question, protesting that he scarcely frequented the Bateau Lavoir and was familiar with it only because Jacob and Salmon would point it out as they passed by. Adding that it was nonetheless there that he must have known the painter Juan Gris, Malraux briskly changes the subject, preferring to discuss his role as Minister of Culture with respect to the administrative question of the building's preservation. As for La Tête 
d'obsidienne, he says in the same interview, «Mon livre n'est pas du tout un livre sur Picasso.» Rather, once inscribed in Le Miroir des limbes, it will serve as a symmetrical pendant to the section of the volume to be dedicated to de Gaulle. ${ }^{10}$

These remarks, while they raise the matter of Malraux's bifurcated sensibilities, are perhaps somewhat disingenuous. Malraux notes in La Tête d'obsidienne that the musée imaginaire had its genesis in his meditations of the nineteen forties. Critics of his art writings, however, have noted its source in his earliest writings, including those on the "Cubist poets," and on Lautréamont, Galanis, and Maurras. ${ }^{11}$ Meyer Schapiro, Gombrich, and others have proposed possible models among philosophers and art historians. ${ }^{12}$ Scholars have traced some of Malraux's notions to Cubist theories of art and to his uneasiness with those proposed by Surrealism. ${ }^{13}$ The extent of Malraux's debt to the painters and poets of Cubist circles has, however, never been fully limned. In uttering Apollinaire's name along with those of Jacob and Salmon in a book dedicated to Picasso, Malraux, hints, in counterpoint to his public pronouncements, at the depth of his youthful engagement with the works and the words of his elders in la bande Picasso. A master puppeteer - he invented Clappique - Malraux, at least fleetingly, lets the strings show.

It is generally impossible to point to a single source of aesthetic inspiration, as variations on a number of themes Malraux addresses can be found in the works of most of the poets of Picasso's circle as well as in the writings of Kahnweiler, who was not only a publisher and art dealer, but also a chronicler of Cubism."

Finally, many of the same motifs can be gleaned from Picasso's own often witty and sometimes contradictory statements that had been published over the years in a number of works with which Malraux, in the Le Monde interview, acknowledged familiarity. ${ }^{15}$ The notion of art as a closed artistic universe that vies with nature's creation is one Malraux would have encountered in the words and works of Apollinaire, Reverdy, Jacob, and Kahnweiler, and Picasso.

The refusal of illusionism and decoration was a commonplace in the art writings of the time. ${ }^{16}$ Picasso the sorcerer and alchemist of La Tête d'obsidienne $(59,112)$ is not Malraux's unique invention but a portrayal consistent with that of Andre Salmon, for instance, who wrote in 1912 of «le Prince-Alchimiste, ce Picasso qui fait songer a Goethe, à Rimbaud, a Claudel .....> ${ }^{17}$ Long before Malraux wrote about Galanis, Apollinaire had observed, in a 1907 essay on Matisse, that the artist forms his artistic personality through confrontation and struggle with the works of other artists and with other arts and scripts (A, II, 101-2). In writing of African art Apollinaire suggested, as Malraux does in La Tête d'obsidienne, that it was important to modernism, not only for its formal qualities, but also for its invocation of the sacred (18-19; A, II, 1415). This same religious spirit, Apollinaire remarked, was to be found in the sculptures of Archipenko, who had contemplated the arts of the Orient, Greece, and Egypt as well as the mystical works of Africa and Oceania. The spiritual, he suggested, was a major impulse in modernism as well as the source of the purest art (A, II, 656-61). In Apollinaire's writings, as in Malraux's, the gods are long dead, but can be resuscitated through art. For Apollinaire, 
who did not hesitate to distort Hermetic teachings, the artist is a demiurge who creates in his own image, and the gods of antiquity are sacred precisely because they are the products of the ineffable spirit of human creation. Malraux, like Apollinaire, suggests that Picasso's art vies with the sacred $(29,38)$, that the painter is a heroic artist and his work a series of triumphant metamorphoses. Like Apollinaire too he links Picasso's name with Michelangelo's (36-7; A, II, 398, 875).

The points of conjuncture between Malraux's portrait of Picasso and Apollinaire's are too many to list here. But in considering the poet's place in Malraux's artistic lineage, it is perhaps useful to note two coincidences of expression, one from the La Voie Royale (1930), which I cite without comment, and the other from La Tête d'obsidienne. In La Voie royale, Perken remarks, «Les musées sont pour moi des lieux où les oeuvres du passé, devenues mythes, dorment, - vivent d'une vie historique - en attendant que les artistes les rappellent à une existence réelle. Et si elles me touchent directement, c'est parce que l'artiste a ce pouvoir de résurrection» (OC, 398). In 1905, Apollinaire published his first piece of art criticism, a lyric essay entitled «Picasso peintre» which evokes the paintings of the Blue and Rose Periods. That essay begins, «Si nous savions, tous les dieux s'éveilleraient. Nés de la connaissance profonde que l'humanité retenait d'elle-même, les panthéismes adorés qui lui ressemblent se sont assoupis. Mais malgré les sommeils éternels, il y a des yeux où se reflètent des humanités semblables à des fantômes divins et joyeux» $(A, I 1,19)$.

In Le Poète assassiné of 1916, Apollinaire presented a fictional account of his first meeting with Picasso: At the end of a cold, dark hall in a «maison sans étages,» the poet Croniamental knocks on a strange door. When it opens he sees a painter dressed in blue and barefoot surrounded by a flock of paintings. «Dans l'atelier, semblable à une étable, un innombrable troupeau gisait éparpillé, ćétaient les tableaux endormis et le pâtre qui les gardait souriait à son ami.» The painter, «l'Oiseau de Benin,» is Picasso, of course, and the «maison sans étage» the Bateau Lavoir (A, I, 255). Years later, in Malraux's account of his visit to Picasso's studio in Mougins, the painter is gone, but Jacqueline turns to a photograph and announces, «Tu vois, Pablito, ton ami est venu ...» (12). It is difficult, in reading Malraux's insistent and affecting evocations of Picasso's cluttered quarters with their sleeping paintings and sculptures, not to think of Apollinaire. As if to answer any lingering questions of affinity, however, Malraux includes the following anecdote at the end of the volume. Visiting with Jacqueline in Vauvenargues, as he had at the book's beginning in Mougins, the writer hears her say that she and Picasso lived there, but that they never really settled in. To this Malraux replies, «Vous êtes-vous jamais installés quelque part? Si j'en juge par Mougins, c'étaient les troupeaux de tableaux qui s'installaient. Et se reproduisaient en toute hâte. Vous deux, vous gardiez les moutons....» (247).

With Jacqueline as his guide, Malraux forges his way through a tropical underbrush of paintings in Picasso's atelier ${ }^{19}$ and thinks about le Douanier Rousseau whose tomb bears Apollinaire's poem engraved by Brancusi. He remembers his visit when Picasso was painting Guernica and sketches seemed to crawl like cockroaches up into the 
painting (17). He steps amid piles of paintings strewn about like leaves swept up by a hurricane (27). He observes that Picasso's collection of paintings by others does not resemble the painter and wonders at the canvases and colors in endless discourse with one another.

Entering a long room haunted by death, he observes a planet of forms that never existed (30) consisting of sculptures and fragments of sculptures as astonishing in their diversity as the stones and sea creatures of the depths. La Femme d la poussette (Woman with Baby (arriage), has become the spirit of the amassed works torn, he says, from their furious sleep. With her vaguely Oriental coiffure and her insect eyes, she seems to be watching over the multitude, or perhaps to have sprung forth from it $(27-29,35)$. Were Picasso's sand pie faced reaper among the silent statues, it too, Malraux muses, would keep watch and howl (34-5). «Vous savez qu'on a découvert des clefs des songes à Babylone et en Chine,» he tells Jacqueline, adding that it is all very reminiscent of Freud. Civilisations pass, he goes on, but the spider and octopi of Babylonian myth are the same as ours (41). As for the animistic accumulations of forms, liberated and orphaned by their Maker's passing, they await metamorphosis in the room reserved for them in the musée imaginaire.

Leaving this eerie purgatory, Malraux continues on in his initiate's voyage of descent and illumination, to visit the paintings born of Picasso's last furious battle with Creation. ${ }^{20}$ The canvases remind him of an invasion of Martians or of the invasion of opium in Saigon. When things were going well, Jacqueline recounts, Picasso would comedown from his atelier saying, «Il en arrive encore! Il en arrive encore!» (72)

Malraux's Lunes en papier also enclosed a pullulating landscape of sleepy and restless forms ruled by a female figure who resembles an insect. "On m'appelle la Mort, she declares at the tale's end, «mais vous savez bien que je suis seulement l'Accident» (OC, 145). A languorous femme fatale in the fin de siecle tradition and an androgynous democratic new woman of a new century, Malraux's queen rules a dreamily passive and futile realm of eroticized diablerie. Lune's conflation of the proliferation of the insect world with an accumulation of gratuitously metamorphosing geometric and biomorphic forms is at once a pastiche of symbolism and modernism and a negative parable of the avant-garde. ${ }^{21}$ As for Malraux's unorthodox, cigarette-smoking queen in smoking jacket, she is a mysogynistic personification of contemporary art's capitulation to fantasy. From here to Charles Maurras, whose preference for the "construction" of L'Action Française over "intellectual anarchy" Malraux applauded in his 1923 preface to Mademoiselle Monk, is perhaps not so far."

In the novels of Malraux's mature years, farfelu drollery and diablerie are relegated to the margins, and heroic and humanist values obtain. Nevertheless, folly threatens always to invade the body of his works. «Vous voyez ma tête?» Clappique would ask in La Condition humaine, "Voilà où mènent vingt ans de fantaisie héréditaire. Ça ressemble à la syphilis» $(O C, 528)$. «Comme Clappique," Jacqueline Machabéis argues, Picasso plonge dans les domaines du chaos, de l'animalité et des instincts. Mais alors que l'homme de l'apparence s'y abîme en perdant toute consistance, l'artiste domine la 
matière qu'il affronte.»13 The works of Picasso and of Goya (whose name Malraux invokes throughout $L a$ Tête d'obsidienne) are paradigmatic for the author because they represent mastery over one's devils and destiny through Promethean vying with Creation. In Saturne (1950) Malraux remarks that Goya made his demons into his familiars, as clowns do their tamed animals. It is a matter of the artist's mastering his nightmares, Malraux suggests, and of his fashioning of this raw material a language that speaks with the accent of the eternal. ${ }^{24}$

«Les objets d'art ne sont que de leur temps,» Malraux writes, «les oeuvres d'art sont aussi du nôtre. Plus pour cause d'immortalite» (173). «Alors d'un côté,» Malraux's Picasso remarks, «il y a toutes les images que les gens fabriquent. Enorme! ... Des musées, des collections ... les calendriers ... les timbres! De l'autre côté il y a le Petit Bonhomme» who fashions his images all alone (134).

Mere objects for Malraux exist only in historical time. Art alone is subject to metamorphosis and eternal life. Massed together and indistinguishable from one another, Picasso's forms murmur in chorus a «langage secret» 36 ). The carnivalesque demiurge and prototypical creator of La Tête d'obsidienne is gone, but he has left behind a treasurehouse of heteroclite forms sprung prolifically from a little man in a conical hat (130).

Critics have remarked that in La Tête d'obsidienne and Le Miroir des limbes Malraux accepts, as he once could not, the phenomena of an individual and collective unconscious and of childish wonder. ${ }^{25}$ Nevertheless, it is worth pointing out that Malraux's détente with his own demons is only provisional. In La Tête d'obsidienne, paintings and sculptures do constant battle within themselves, with other art, and with Creation. Despite the resurrection that awaits Picasso's restive paintings and sculptures, and despite their communion, they are still reminiscent of La Tentation de l'Occident's (1926) disputatious canvases $(O C, 87)$, and of a youthful Malraux's anxious evocations of the pernicious disorder of the West. In La Tête d'obsidienne, as elsewhere, Malraux conjures up a talismanic list of fellow adepts - Picasso and Jacob, Goya and Bosch, Apollinaire and Breton - only to relegate them again to the shadows. "[J]'ai ... peu frequente le Bateau Lavoir," he insists in Le Monde. La Tête d'obsidienne is not about Picasso, he goes on, but is to be a compliment to Le Miroir's meditation on de Gaulle. ${ }^{26}$ While these statements are doubtless true, they perhaps ring somewhat hollow. Picasso's more mirthfully ironic pronouncement comes to mind: «L'art nègre, connais pas!» «Je juge cette longue querelle,» Apollinaire had written in 1918, «de la tradition et de l'invention/De L'Ordre et de l'Aventure.»" Torn between order and adventure, between Maurras and Jacob, de Gaulle and Picasso, Malraux's own contentious universe of orphaned forms quarrels on. 


\section{NOTES}

${ }^{1}$ André Malraux, La Tête d'obsidienne (Paris: Gallimard, 1974). Page references to this work appear in the text.

${ }^{2}$ For a very critical reading of $L a$ Tête d'obsidienne in general and with respect to Malraux's role in the 1966 exhibition, see Pierre Cabanne, «Malraux contre Picasso,» L'Oeil 226 (1974): 58-59.

${ }^{3}$ «André Malraux et le Musée imaginaire» Fondation Maeght, Saint-Paul-de Vence, 13 juillet-30 septembre 1973.

4André Malraux, Les Noyers de l'Altenburg (Paris: Gallimard, 1948) 90, and Le Miroir des limbes (Paris: Gallimard, «Bibliotheque de la Pléiade,» 1976) 8. For critical discussion of La Tête d'obsidienne, see: E.H. Gombrich, "Malraux's Philosophy of Art in Historical Perspective," Malraux, Life and Work ed. Martine de Courcel (New York: Harcourt Brace Janovich, 1976) 177-9; Renée Riese Hubert, «Le Dialogue entre André Malraux et Pablo Picasso,» André Malraux et l'art, ed. Walter G. Langlois, Reoue des Lettres Modernes 537/542 (Paris: Minard, 1978) 73-82; Thomas Jefferson Kline, "Malraux's Picasso: A Portrait of the Artist as a Young Malraux," Mélanges Malraux Miscellany 13.2 (Autumn 1981): 2-13; Jacqueline Machabéis, «Malraux et l'art comme 'anti-destin,'» André Malraux, l'homme des univers, Actes du Colloque, Dec. 5-8, 1986 (Paris: Comité National André Malraux, 1989) 161-67; Machabéis, «Mécanismes de la mémoire des lieux dans Le Miroir des limbes," André Malraux: Unité de l'oeuore, unité de l'homme (Paris: La Documentation Française, 1989) 227-41.

5Steve Saler, "Malraux still the man of action," Boston Sunday Globe 19 Dec. 1971: A-61. See Jean Lacouture, André Malraux: une vie dans le siècle (Paris: Seuil, 1973) 408-410.

${ }^{6}$ André Malraux, Oeuvres complètes (Paris: Gallimard, «Bibliothèque de la Pléiade,» 1989) $I, 334$. Subsequent references to $O C$ appear in the text.

'In La Tête d'obsidienne, Picasso suggests that painting is not about copying nature, but about the use of names and signs (110). The notion is one that has been attributed to Picasso elsewhere as well. See, for example, Hélene Parmelin, Picasso dit ... (Paris: Gonthier, 1966) 29-30; Dore Ashton, ed., Picasso and Art: A Selection of Views (New York: Viking, "Documents of 20th-Century Art," 1972) 19, 132. For similar discussion of the use of signs in Cubist art, see Daniel-Henry Kahnweiler, «Mallarmé et la peinture,» Les Lettres 3 (1948): 66-67. For further discussion of signifiers in Picasso's Cubism, see Rosalind Krauss, "Re-Presenting Picasso," Art in America Dec. 1980: 91-94.

${ }^{8}$ For consideration of this imagery, see, for example, David Bevan, André Malraux: Towards the Expression of Transcendence (Kingston, Canada: McGill-Queen's University Press, 1986) 32-40, 66-72.

'Jean Lacouture 31. For analysis of Malraux's early artistic development, including his apprenticeship in Cubist circles as well as his more troubled coexistence with Dada 
and Surrealism, see: Walter Langlois, "The Début of André Malraux, Editor (Kra, 1920-1922)," PMLA 80.1 (1964): 111-122: reprinted in Via Malraux: Ecrits de/Essays by Walter Langlois ed. David Bevan (Wolfville, Nova Scotia: The Malraux Society, Acadia University, 1986) 13-34; André Vandegans, La Jeunesse littéraire d'André Malraux: Essai sur l'inspiration farfelue (Paris: Jean-Jacques Pauvert, éditeur, 1964) 17-140; Pascal Sabourin, La Réflexion sur l'art d'André Malraux: Origines et eoolution (Paris: Klincksieck, 1972) 17-61; Lacouture 22-56; Langlois, «Fels, Anarchisme et Action: Un Courant oublié de l'avant-garde,» in Via Malraux 35-68; Robert Thornberry, «Des origines de la poésie cubiste au début des Conquérants: le développement de l'esthétique de Malraux,» $L e$ liore dans la vie et l'oeuore d'André Malraux, Colloque André Malraux, Nov. 13-15, 1986 (Paris: Klincksieck, 1988) 122-32; Jean-René Bourrel, «Malraux à la NRF: l'esprit nouveau et la création littéraire,» André Malraux: Unité de l'oeuvre 111-27.

${ }^{10}$ See «Un Entretien avec André Malraux,» Le Monde 15 Mar. 1974: 1, 22. Malraux's reticence here is notable, especially in light of his admission the year before: «... ma formation littéraire, appelons ça cubiste: Apollinaire, Max Jacob, etc., et mon goût des grands romantiques en même temps, c'était une chose très rare à l'époque.» Guy Suarès, Malraux, celui qui vient (Paris: Stock, 1974) 39. It is true that Malraux probably had relatively little direct contact with the Bateau Lavoir, which had largely ceased to be a meeting place for Picasso and his group by 1912 or 1914. Juan Gris did remain there until 1922, as Malraux's comment suggests. See Fernande Olivier, Picasso et ses amis (Paris: Stock, 1933) 24; Jeanine Warnod, Washboat Days, trans. Carol Green (New York: Grossman Publishers, 1972) 20, 195, 226-8.

${ }^{11}$ See André Malraux, «Des Origines de la poésie cubiste,» La Connaissance (Jan. 1920): 38-43; Malraux, "La Genèse des Chants de Maldoror » Action 3 (April, 1920): 33-35; Malraux, Preface to catalogue of «Exposition D. Galanis, " Galerie de la Licorne, 3-18 March, 1922; Malraux, preface, Madememoiselle Monk by Charles Maurras (Paris: Stock, 1923) 7-9; Sabourin 50, 60, 72-3.

${ }^{12}$ See Meyer Schapiro, "The Artist's Creative Process," Saturday Review 4 Feb. 1950: 37; E.H. Gombrich, "André Malrux and the Crisis of Expressionism," Burlington Magazine Dec. 1954: 374-77. For a less critical evaluation of Malraux's art writing, see Pierre Daix, «Malraux écrivain d'art ou le point de vue du XXe siècle,» Gazette des Beaux Arts 6th ser. 89, supp. 1296 (Jan. 1977) 1-4. For discussion of critical response to Malraux's art writings, see Stefan Morawski, L'Absolu et la forme: l'esthétique d'André Malraux, trans. Holande Lamy-Grum (Paris: Klincksieck, 1972) 143-54.

${ }^{13}$ See, for example, Vandegans 44-46, 73-4; Sabourin 39-42; Lacouture 31, 124-26; Langlois, «Fels» 59-67; Thornberry 124-5; Bourrel, 111-18.

${ }^{14}$ See Kahnweiler, The Rise of Cubism, trans. Henry Aronson (1915; New York: Wittenborn, Schultz, Inc., 1949); Kahnweiler, Juan Gris: His Life and Work, trans. Douglas Cooper (New York: Abrams, 1968-9). 
${ }^{15}$ Malraux insists, in the Le Monde interview, on the authenticity of the conversations reported in La Tête d'obsidienne. At issue are compilations of Picasso's remarks included in books by Brassaï, Frangoise Gilot, and Hélène Parmelin.

${ }^{16}$ See: Guillaume Apollinaire, «Sur la peinture, in Oeurres en prose completes, (Paris: Gallimard, «Bibliotheque de la Pléiade» 1991) vol. II, 7. Subsequent references appear in the text as volume and page numbers preceded by "A;" Pierre Reverdy, «Sur le Cubisme,» Nord-Sud 1 (March 1917): 5-7; Max Jacob, preface, Le Cornet d̀ dés (Paris: Gallimard, 1982) 23; Kahnweiler, Juan Gris 144, 179; Parmelin 32-3.

${ }^{17}$ André Salmon, La Jeune Peinture française (Paris: Albert Messein, 1912) 52. For remarks on other literary evocations of Picasso, see Hubert 73, and LeRoy C. Breunig, "Picasso's Poets," Yale French Studies 21 (1958): 3-9.

${ }^{18}$ For discussion of Apollinaire's treatment of Hermetic materials, see Marie-Jeanne Durry, Guillaume Apollinaire: Alcools (Paris: Société d'Editions d'Enseignement Supérieur, 1956-64) vol. 1, 156-7.

${ }^{19}$ For comments on Malraux's evocation of accumulations, see Machabéis, «Mécanismes de la mémoire,» 236-40 and Machabéis, «Malraux et l'art comme 'anti-destin.'» For further discussion of the these themes as well as others taken up here, see my article, "On Rereading André Malraux: The Collector," Review André Malraux Reoiew 24.1-2 (1992-3): 142-153.

${ }^{20}$ The notion of descent and illumination is consistent with Apollinaire's analysis of Picasso's early work in «Picasso peintre» (A, II, 19-25).

${ }^{21}$ For remarks on Malraux's use of pastiche, see Vandegans 116.

${ }^{22}$ See Malraux, Preface à Charles Maurras 7. For consideration of Maurras's place in Malraux's intellectual evolution, see Vandegans 67-9; Lacouture 45-8, 57; Thornberry, "Questions esthétiques: 1920-1931, André Malraux, homme des univers 125-6; Thornberry, «Des Origines» 123; Bourrel, 112; Thornberry, «Malraux, Maurras et 'Mademoiselle Monk,'» Reoue André Malraux Reoiew 24.1-2 (1992-3): 164-74.

${ }^{23}$ Machabéis «Malraux et l'art comme 'anti-destin'» 166.

${ }^{24}$ See Malraux, Saturn: An Essay on Goya trans. C.W. Chilton (London: Phaidon Press, 1957) 42-3, 46.

${ }^{25}$ See Pascal Sabourin, «Vingt ans après: Pour une Relecture des écrits romanesques et des essais sur l'art d'André Malraux, Le Liơre dans la vie 36; Machabéis, «Mécanismes de la mémoire» 240.

${ }^{26}$ See note 10.

${ }^{27}$ Apollinaire, «La Jolie Rousse,» in Oeurres poétiques (Paris: Gallimard, «Bibliothèque de la Pléiade,» 1965) 313. 